\title{
PACKER TESTING AND BOREHOLE GEOPHYSICAL CHARACTERIZATION OF OBSERVATION WELLS IN A VERTICALLY INTEGRATED KARST AQUIFER IN AUGUSTA COUNTY, VIRGINIA
}

Joel P. Maynard

Virginia Department of Environmental Quality, 4411 Early Rd., Harrisonburg, VA, 22801, USA, Joel.Maynard@deq.virginia.gov

\section{Brad A. White}

Virginia Department of Environmental Quality, 900 Natural Resources Drive, Suite 600, Charlottesville, VA, 22903, USA,Bradley.White@deq.virginia.gov

\begin{abstract}
Geophysical borehole logging and zone-isolation packer testing at adjacent State Observation Wells (SOWs) in Augusta County, Virginia, indicate the presence of shallow and deep horizontal karst conduits that are hydraulically connected by a highly transmissive, vertical fracture network. Despite the presence of a downward open-hole hydraulic gradient, ambient- and pumping-induced water level responses were identical during zone isolation tests in two conduit zones measured in SOW 70 and one conduit zone measured in an adjacent observation well (SOW 70A). Identical hydraulic responses between all 3 monitoring points is interpreted to be the result of a solution-enlarged, vertically oriented fracture network that is capable of muting measurable head differences during zone isolation tests. Results from multiple open-hole flow logging tests within SOW 70 have also shown distinct variations in vertical flow that correspond with seasonal groundwater recharge. The occurrence of these vertically oriented, highly transmissive fracture sets is thought to be coincident with folding within the Staunton-Pulaski thrust sheet, and could be an important mechanism for the vertical integration of distinct hydrologic features in similar structural settings. The series of tests on SOW 70 and SOW 70A has resulted in a better practical and conceptual understanding of the monitored karst aquifer near Staunton and demonstrates the utility in collecting multiple types of borehole geophysical data during different times of the year on karst wells.
\end{abstract}

\section{Introduction}

Observation wells have been used for decades throughout the world to investigate aquifer characteristics and assess the availability and quality of groundwater resources. Despite significant advances in remote sensing and computer modeling, water-level measurements from observation wells remain the principal source of information about how aquifers respond to the hydrologic stresses acting on any given region (Taylor, 2001).

The Virginia Department of Environmental Quality (VDEQ), in cooperation with the U.S. Geological Survey (USGS), currently operates a network of 325 active observation wells throughout the state, the majority of which are located in Virginia's Coastal Plain Groundwater Management Area (Figure 1). Construction details for most of the state observation wells in the Coastal Plain are relatively well known as they were

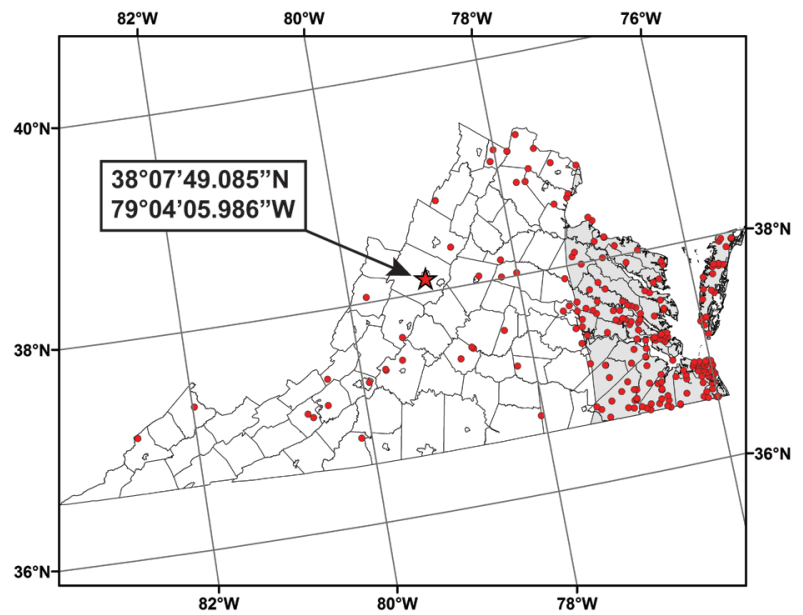

Figure 1. Observation wells operated by the VDEQ and USGS in Virginia. Red star denotes study location. Coastal Plain Groundwater Management Area shaded in gray. Site coordinates NAD83 horizontal datum. 
purpose-built by DEQ or USGS geologists to monitor specific confined aquifers and were cased and screened in a manner preventing communication with overlying aquifers.

State observation wells in areas west of Virginia's Coastal Plain are typically former supply wells completed in deformed sedimentary or crystalline bedrock with construction details that are often highly generalized or unknown. Below surface casing, the open boreholes commonly intersect multiple water bearing fractures or conduits as they were originally constructed to maximize yield. Since 2006, VDEQ geologists have used borehole geophysical tools to characterize the construction of these observation wells in order to better understand their construction and the geology of the aquifers they monitor. This paper discusses the results of one of these studies on State Observation Well 70 (SOW 70) in Augusta County.

\section{Geologic Setting and Background}

The study area is in Virginia's Valley and Ridge Physiographic Province and borders the City of Staunton near the southern headwaters of the South Fork of the Shenandoah River. SOW 70 is located along the axial trace of an unnamed, north-east plunging anticline in the hanging wall of the Staunton-Pulaski fault (Figure 2). The well was drilled in limestone, dolomite, and sandy dolomite of the Conococheague Formation of CambroOrdovician Age (Rader, 1967).

SOW 70 was reportedly drilled to a terminal depth of $76 \mathrm{~m}(250 \mathrm{ft})$ in 1964 as a supply well for a nearby shopping center with a reported yield of $1075 \mathrm{~L} / \mathrm{min}$ (284 GPM). The well was abandoned as a supply for unspecified reasons before eventually being obtained by the state for monitoring purposes. Periodic and later automated groundwater-level measurements have been collected from the well since 1974 and exhibit a relatively stable long-term trend and a seasonal range as high as $4.5 \mathrm{~m}$ (15 ft) (Figure 3). Well construction was first evaluated in 2006 using a black and white borehole camera. The fixed-view camera revealed what appeared to be a single horizontal conduit near the bottom of the well (70 m, $230 \mathrm{ft})$.

In 2010, a shallow observation well (SOW 70A) was installed adjacent to SOW $70(4.5 \mathrm{~m}, 15 \mathrm{ft})$ in order to evaluate the possibility of monitoring both shallow and

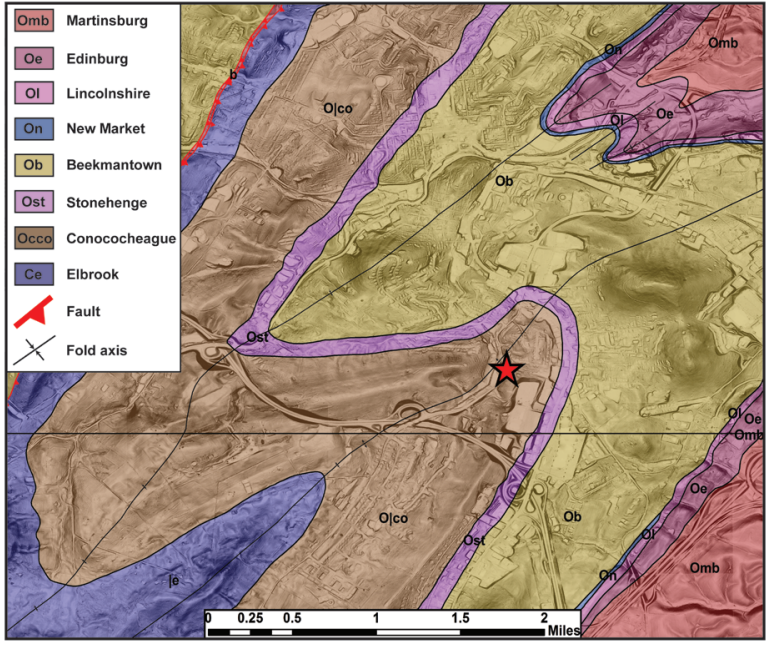

Figure 2. Geologic setting of the Augusta County state observation well site. Geology from Campbell et al., 2006.

deep portions of the karst aquifer at the site. SOW 70A was drilled to a depth of $19 \mathrm{~m}$ (62 ft), cased and grouted to $15 \mathrm{~m}(50 \mathrm{ft})$ and yielded an estimated $568 \mathrm{~L} / \mathrm{min}$ (150 GPM). Air rotary installation of SOW 70A caused significant water level fluctuation in SOW 70 once drilling encountered limestone bedrock at $9 \mathrm{~m}(29 \mathrm{ft})$.

\section{Methodology}

VDEQ initiated geophysical borehole logging at the site in December 2015 following the installation of a roof hatch in the concrete well-house surrounding SOW 70.

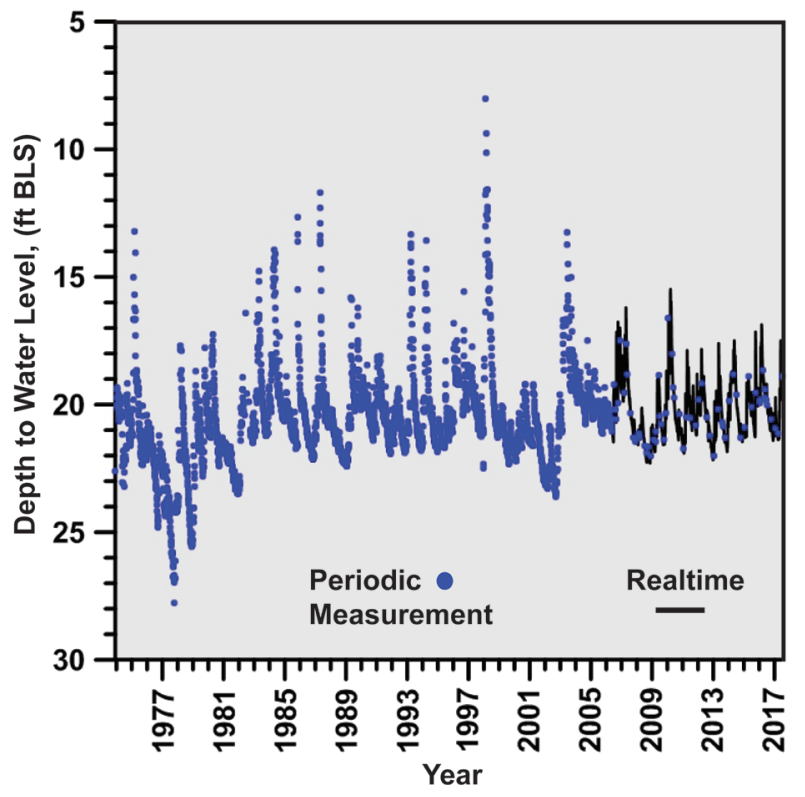

Figure 3. Long term water level hydrograph for SOW 70. 
Logging of SOW 70 included both optical and acoustic borehole imaging, 3-arm caliper, multi-tool (natural gamma, lateral resistivity, 16- and 64-inch normal resistivity, spontaneous potential, fluid resistivity, temperature), and electro-magnetic flow measurements under ambient and pumping conditions. Both boreholes were surveyed with a pan/tilt color borehole camera.

An inflatable packer (Aardvark 4 inch) was installed in SOW 70 from March 24 to May 19, 2016 to measure differential head responses between upper and lower portions of the former supply well and the shallow observation well. The packer assembly was threaded to sections of $50 \mathrm{~mm}$ ( 2 inch) diameter PVC pipe and carefully lowered to a depth of $34 \mathrm{~m}(112.5 \mathrm{ft})$ below land surface (BLS) where geophysical logs indicated the borehole wall was smooth and competent. The exterior of each threaded PVC pipe joint was reinforced with layers of electrical- and pump-tape to prevent possible leakage of rubber gaskets. Vented pressure transducers (Winsitu Level Troll 700s) were installed to monitor water levels in both zones of SOW 70. A vented Aquatroll 200 was installed at the main water bearing conduit in SOW 70A to measure water level and fluid conductance response. On March 24, 2017, after all three probes had collected 15 minutes of data, the packer was inflated with nitrogen gas to a pressure of $1585 \mathrm{kPa}$ (230 PSI). Following 2.5 hours of equilibration, a 3" Grunfos submersible pump was lowered to a depth of $15 \mathrm{~m}(50 \mathrm{ft})$ in SOW 70A and used to stress the well at $45 \mathrm{~L} / \mathrm{min}$ (12 GPM) for 25 minutes. On April 14, 2016 the packer assembly was deflated and lowered to a depth of $64 \mathrm{~m}(211 \mathrm{ft})$ and SOW 70A was this time pumped at $51.4 \mathrm{~L} / \mathrm{min}$ (13.6 GPM)for 103 minutes. In addition to testing for response to pumping induced stresses, the packer assembly was left in the borehole for several weeks to document ambient response to precipitation. Weekly checks were made to ensure proper packer inflation and tape-down measurements were made using an electronic tape to check the transducer data for instrument drift. The maximum difference between hand-taped and recorded measurements was $4.2 \mathrm{~cm}$ $(0.14 \mathrm{ft})$, but most transducer data deviated less than $1.2 \mathrm{~cm}(0.04 \mathrm{ft})$ from tape-down measurements. Relative water depths were converted to water level elevations using an onsite permanent benchmark and a Sokkia SDL30 Digital Level and fiberglass survey rod.
On September 17, 2015, the borehole electromagnetic flowmeter was calibrated in a specially constructed clear plastic flow-cell that enabled comparison of the device's reported flow rates to volumetric and impellerdriven flow-meter rates. The instrument calibration was again checked on June 14, 2016 at 22 induced flow rates ranging from $21.4 \mathrm{~L} / \mathrm{min}$ (5.65 GPM) of downward flow to $20.8 \mathrm{~L} / \mathrm{min}$ (5.50 GPM) of upward flow. The tool's measured flow response was in close agreement with induced rates (Figure 4). Open borehole flow logging of SOW 70 was performed on three separate occasions during the 2016 water year and once near the beginning of the 2018 water year: December 9, 2015, May 19, 2016, June 15, 2016, and November 13, 2017.

\section{Results}

Camera logging of the shallow observation well SOW 70A revealed that the well had a good casing seal and intercepted two small (less than $15 \mathrm{~cm} / 6$ in thick) horizontal conduits developed along bedding between

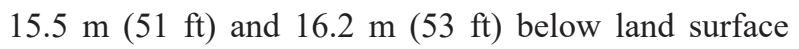
(bls). The second camera log of SOW 70 was made with a pan/tilt color camera that allowed for a more thorough inspection of the well. The camera log of the former supply well showed an irregular casing contact with bedrock at $29 \mathrm{~m}(94 \mathrm{ft})$ that was obscured on the first camera $\log$ in 2006 due to an accumulation of bacteria and corrosion.

Ambient borehole flow measurements made in SOW 70 on December 9, 2015 detected 6.8 L/min (1.8 GPM) of groundwater flow from the compromised casing seal at $29 \mathrm{~m}$ (94 ft), down the borehole to the horizontal conduit

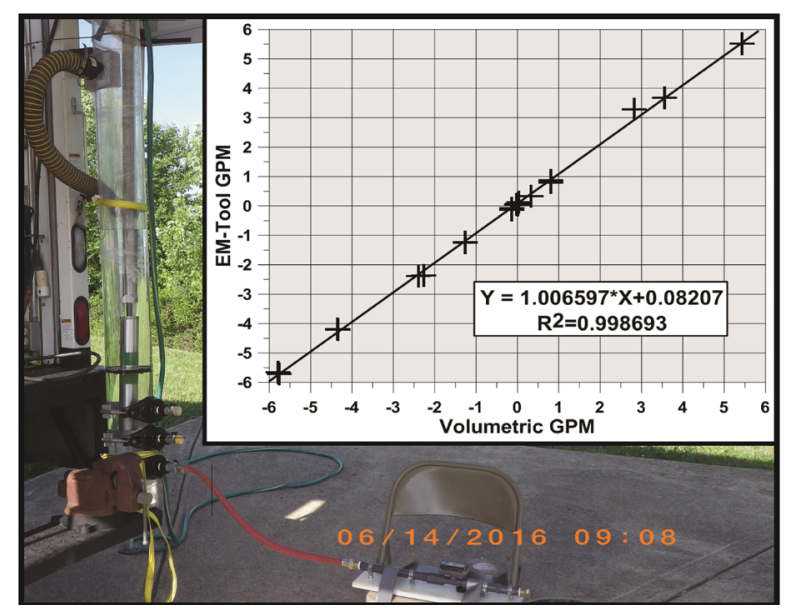

Figure 4. Results of electro-magnetic flowmeter calibration check performed June 14, 2016. 
at $70 \mathrm{~m}(230 \mathrm{ft})$. The downhole flow between the two zones implied that the hydraulic head for the upper zone was higher than the hydraulic head for the conduit at $70 \mathrm{~m}$ (Johnson et al., 2005) (Figure 5).

Isolation of the compromised casing seal from the receiving conduit produced no significant head differences under ambient conditions. Pumping of SOW 70A produced identical drawdown responses in both zones of SOW 70 despite the limited amount of stress $(8.53 \mathrm{~cm} / 0.28 \mathrm{ft}$ drawdown) that could be applied to the aquifer with the available test pump (Figure 6). Pumping and ambient water level responses were identical at both packer depths in SOW 70. During both pump tests on SOW 70A, the pressure / conductivity probe stationed below the test pump in SOW 70A recorded a slight decrease in specific conductance of groundwater from the shallow conduit during both pump tests $(\sim 15 \mathrm{uS} / \mathrm{cm})$. Data collected the month following pump testing showed water levels in each zone responded identically to recharge (Figure 7). On May 26, 2016, a small increase in groundwater specific conductance in response to precipitation was recorded at the conduit in SOW 70A, a change that preceded water level increases at the site by 2 days. Semi-diurnal earth tide signals, due to lunar dilation of water bearing fractures, were present in all zones monitored, although less prevalent in the shallow SOW 70A.

Two earthquake responses were recorded by the dataloggers due to a Richter M7.0 earthquake in Japan on May 15, 2016, and a M7.8 earthquake in Ecuador on May 16, 2016 (Figure 8). Although teleseismic water level oscillations were noted in both zones of SOW 70 and SOW 70A, the response from the lower conduit of SOW 70 exhibited the highest amplitude $(7.62 \mathrm{~cm} /$ $0.25 \mathrm{ft}$ ). Water level oscillations began 48 minutes after the M 7.0 Japan earthquake and lasted for 44 minutes. The M 7.8 earthquake produced higher amplitude water level oscillations in all zones 14 minutes after it occurred in Ecuador and fluctuations lasted for almost an hour.

Borehole flow logging was conducted the day of final packer removal on May 19, 2016 and later on June 15, 2016 following a successful flow-cell calibration check, detecting significant downhole flow on both occasions (3.0 L/min / $0.8 \mathrm{GPM}$ and $2.3 \mathrm{~L} / \mathrm{min} / 0.6 \mathrm{GPM}$ respectively. Borehole flow data was also collected on November 13, 2017 in a period of seasonally low

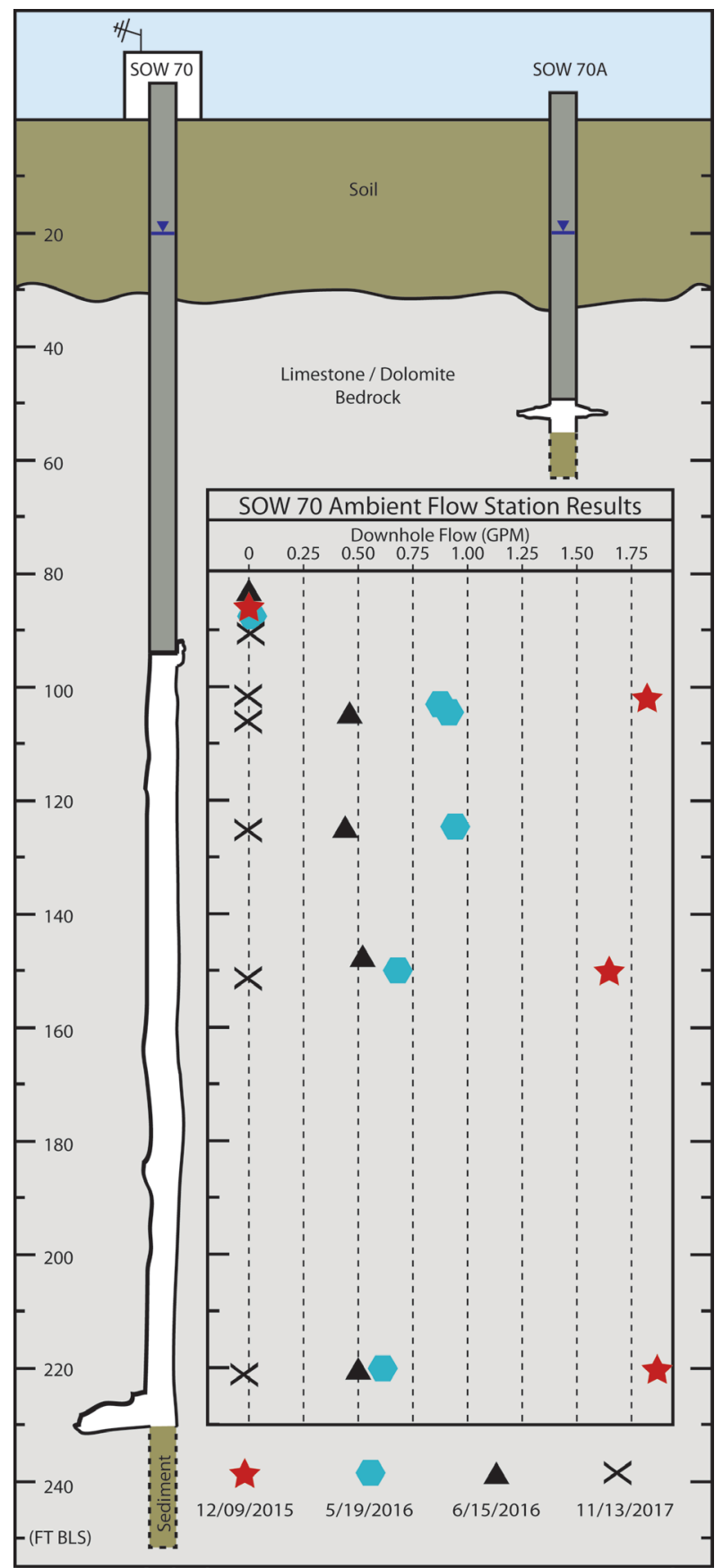

Figure 5. Schematic summarizing construction and ambient open borehole flow conditions observed during geophysical logging.

groundwater levels during which no significant vertical flow was detected (Figure 5).

\section{Discussion}

Four open-borehole flow logs conducted during the winter to early summer months have documented ambient downward flow between shallow and deeper 


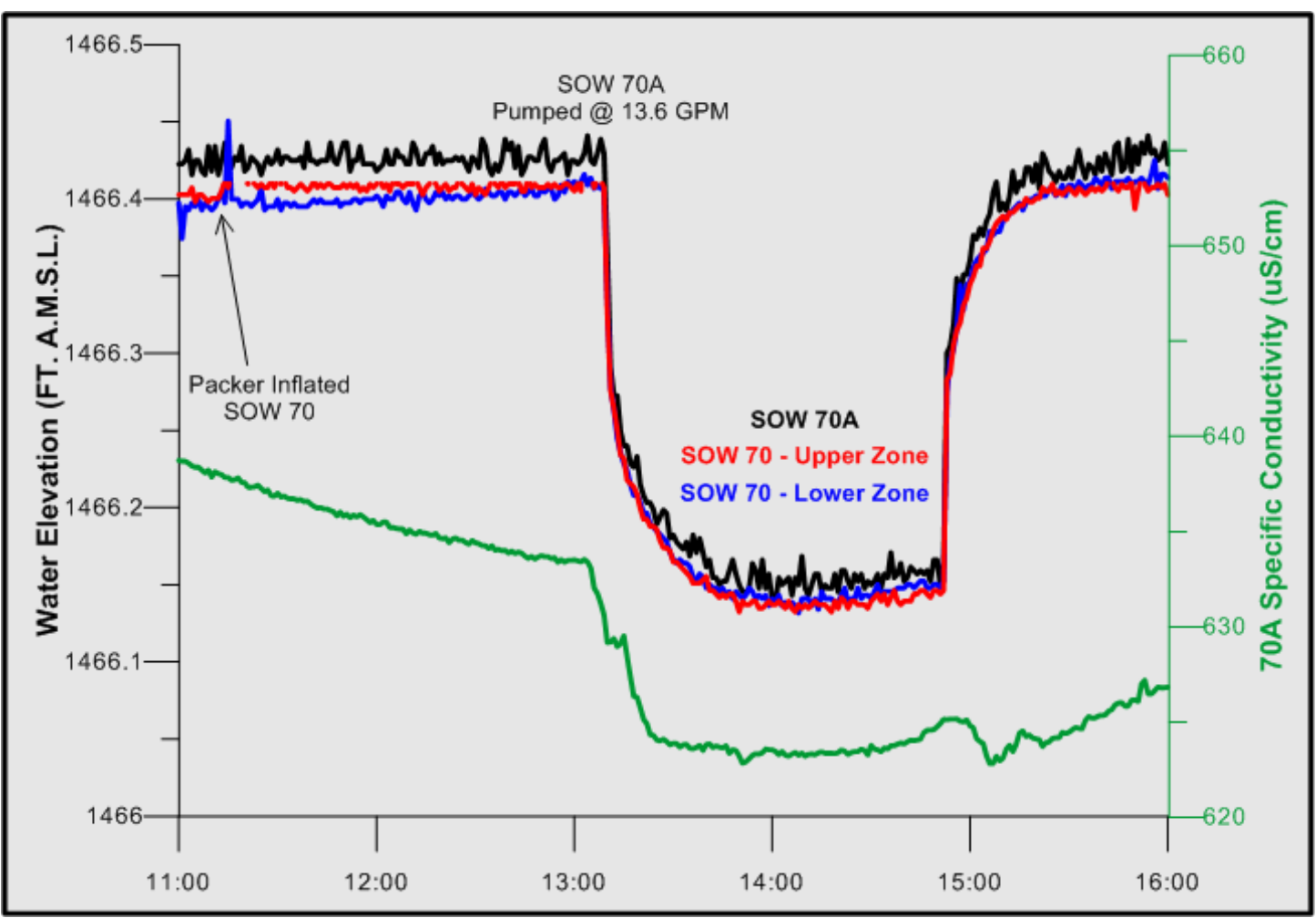

Figure 6. Groundwater level and specific conductivity responses to pumping of SOW 70A on April 14, 2016. Green line shows specific conductance of groundwater at the main water bearing conduit $15 \mathrm{~m}(52 \mathrm{ft})$ bls in SOW 70A.

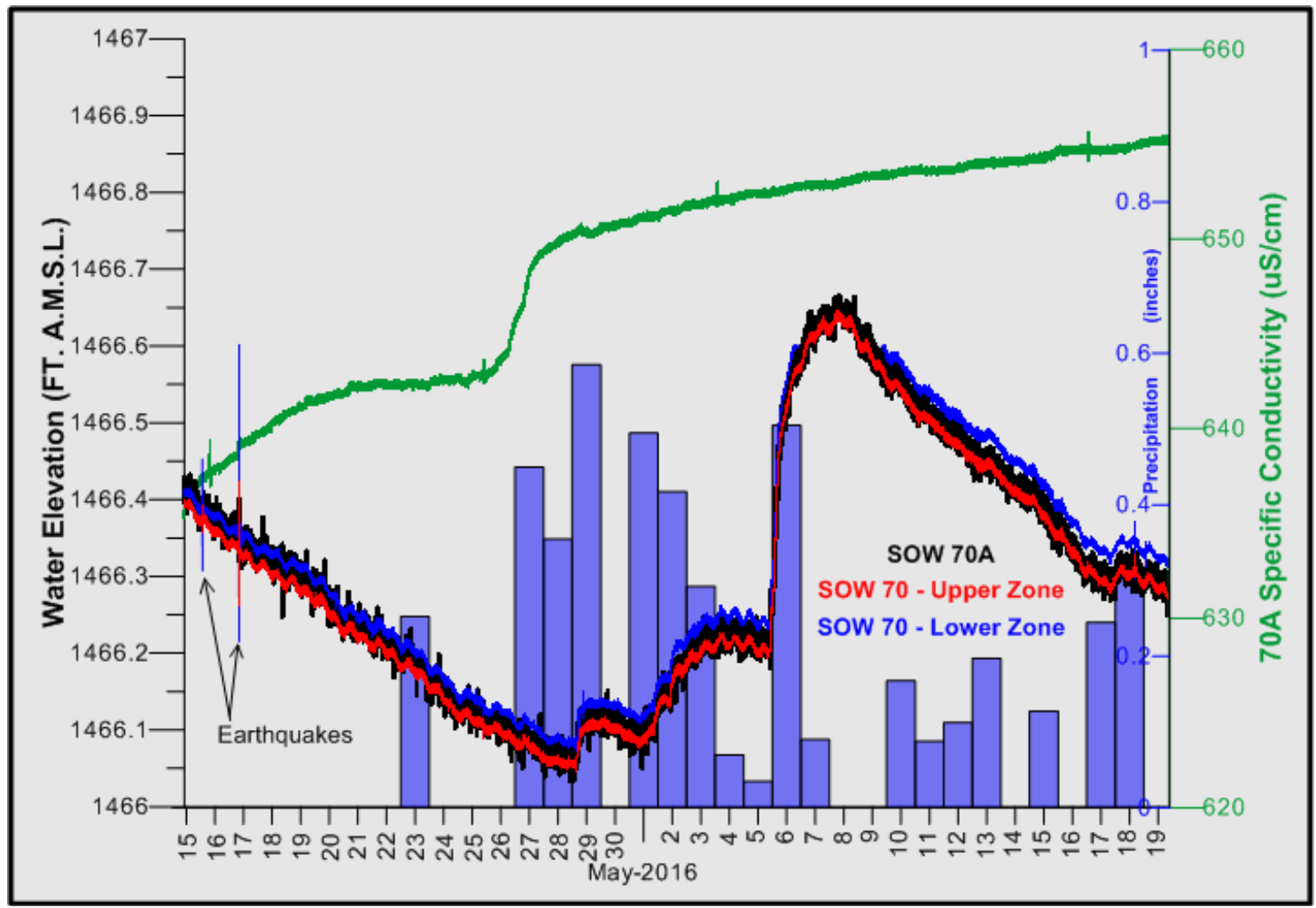

Figure 7. Ambient responses to precipitation, earthquakes, and semi-diurnal lunar fracture dilation from April 15 to May 19 2016. Inflatable packer stationed at $64 \mathrm{~m}(211 \mathrm{ft}$ ) bls. 


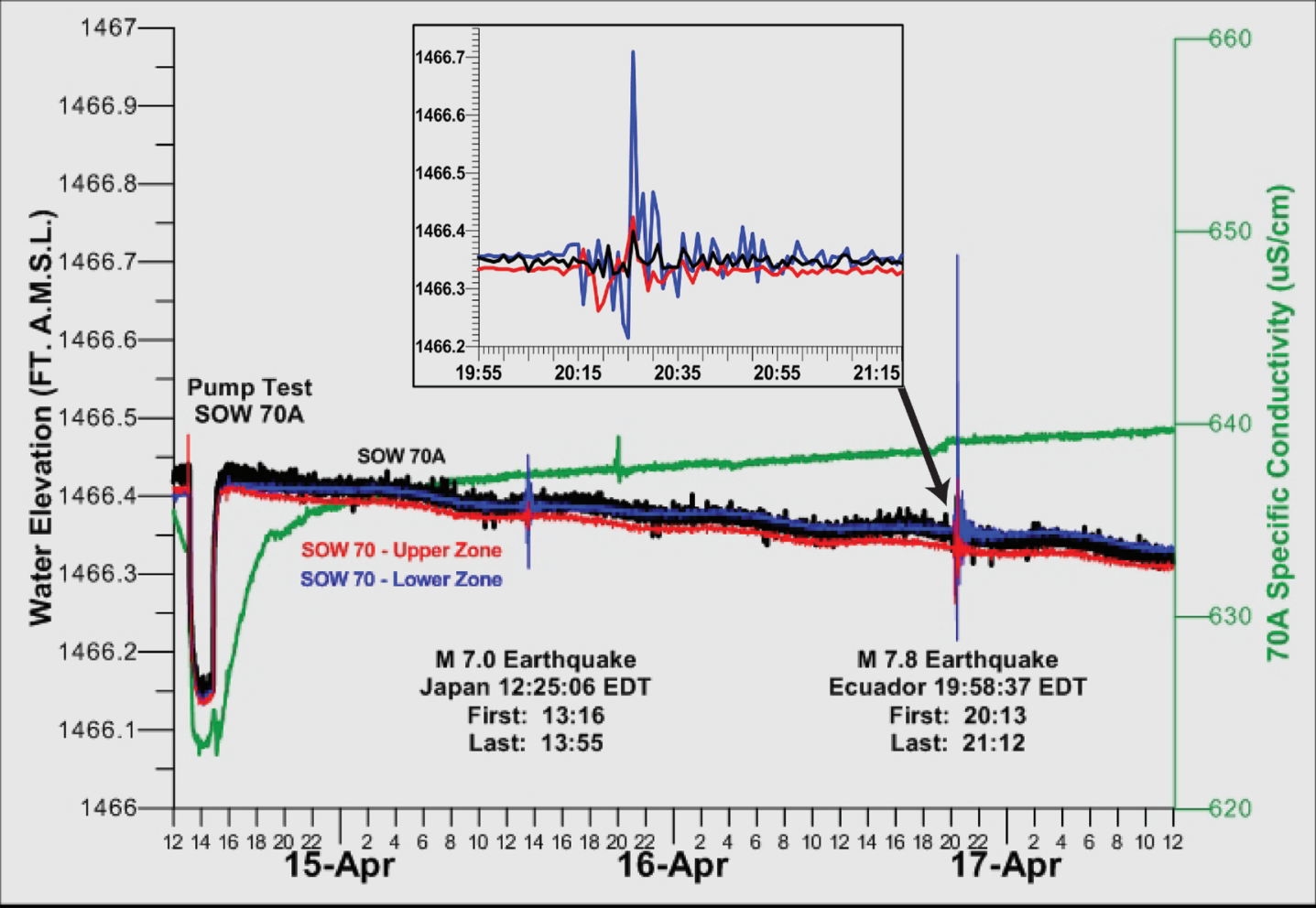

Figure 8. Teleseismic water level oscillations recorded in SOW 70 and $70 \mathrm{~A}$ on April 15 and 16, 2016. Inflatable packer stationed at $64 \mathrm{~m}(211 \mathrm{ft})$ bls.

parts of the aquifer at the site. The downhole flow rate was higher during the winter, when most groundwater recharge occurs in the region, and lower in the late spring and summer months when recharge rates tend to slow in response to plant growth and increased evapotranspiration (Nelms and Moberg, 2010).

The fact that isolation of the two zones resulted in no significant difference in ambient and pumping water levels could be the result of equipment failure or natural aquifer conditions. Borehole flow logging and packer testing are prone to error for a variety of reasons, but most commonly due to improper setup, calibration, or a highly irregular borehole shape that does not allow for proper instrument seal. During all tests, caliper and video logs were used to position the flow instrument and packer seal at smooth unfractured intervals to reduce the chance for error due to flow bypass. Bracketing of the borehole flow tests with flow-cell calibration checks further increased confidence in ambient downward flow detected in SOW 70. The lack of significant ambient and pumping head differences between isolated zones, coupled with persistent ambient open-borehole flow is therefore thought to reflect the presence of hightransmissivity vertical features that locally integrate the bedding plane conduits yielding water in both wells. In effect, the open borehole in SOW 70 acts as a high transmissivity artificial conduit in an already well integrated aquifer. The vertical fracture network within the aquifer is capable of muting measurable head differences during zone isolation tests as flow gradients within the wellbore shift instantaneously to other equally transmissive parts of the aquifer.

Although only horizontal water bearing features are noted in the exposed portions of both boreholes, vertical integration of the karst aquifer is supported by the presence of steeply dipping sealed fractures in geophysical logs, the presence of steeply dipping solution-enlarged fractures observed in nearby outcrop, and the site's location along the axis of a plunging anticline where axial-plane fracturing is usually more prevalent (White, 1988). It is possible that at a significantly higher pumping rate $(\sim 378 \mathrm{~L} / \mathrm{min}, \sim 100 \mathrm{GPM})$ vertical transmissivity between the two zones may be exceeded, resulting in measurable differences between zone-isolated pumping heads.

Groundwater conductance changes were recorded at the water bearing conduit in SOW 70A during pumping and 
in response to recharge, though the magnitude of response was minor $(<15 \mathrm{uS} / \mathrm{cm})$ and near the rated accuracy of the conductivity logger $(+/-0.5 \%$ of reading, $3 \mathrm{uS} / \mathrm{cm})$. The fluid conductance declines recorded during pumping of SOW 70A, followed by a delayed rebound after water level recovery, probably relate to displacement of relatively stagnant borehole water with groundwater more representative of aquifer chemistry. In contrast, the slight fluid conductance increase on April 26 occurred during the onset of rains that soaked the area following an unusually dry late winter and preceded groundwater level increases in the aquifer by two days. The reason for this fluid conductance increase is poorly understood but may reflect infiltration or flushing of road salts or other contaminants from upland urban landscapes. Similar conductance increases that preceded minor or muted spring discharge responses were determined to be due to recharge carrying seasonally applied road salts in the northern Shenandoah Valley (Doctor et al., 2011).

Teleseismic water level responses have been recognized in SOW 70 since the well was equipped to record water levels at 5 minute intervals in 2006. The well commonly responds to large ( $>$ M 7.0) earthquakes around the globe - yet failed to respond to the August 23, 2011 M 5.8 earthquake in Mineral, Virginia (Sheets, 2015). The higher frequency (1 minute) data collection rates used during the zone isolation tests allowed for a more detailed observation of teleseismic water level response at multiple depths in the karst aquifer. The higher amplitude and duration response of the deeper conduit during both earthquakes could be a reflection of differences in aquifer transmissivity and storage that manifest as greater amplification of seismic water level oscillations in the lower part of the aquifer (Bredehoeft et al., 1965). Slight changes (+/- $1 \mathrm{uS} / \mathrm{cm})$ in specific conductance recorded around the time of both earthquakes in SOW 70A (Figure 8) are below the rated accuracy of the probe and occur either too long after or before each quake to be related to seismicity.

In conclusion, geophysical logging and packer testing have resulted in an improved understanding of aquifer conditions monitored by the Augusta State Observation Well and have demonstrated the utility in collecting flow data during different times of the water year to better understand the dynamics of groundwater flow in fractured rock aquifers.

\section{References}

Bredehoeft JD, Cooper HH, Papadopulos IS, Bennet RR. 1965. Seismic Fluctuations in an Open Artesian Water Well. U.S. Geological Survey Professional Paper 525-C, pp C51-C57. https:// pubs.er.usgs.gov/publication/pp525C.

Campbell EV, Hibbitts HA, Williams ST, Duncan IJ, Reis JS, Floyd JM, Wilkes GP. 2006. Interstate 81 Corridor Digital Geologic Compilation: Virginia Division of Mineral Resources Open-file Report 06-01. https://www.dmme.virginia.gov/commerce/ ProductDetails.aspx? productID $=2514$.

Doctor DH, Farrar NC, Herman JS. 2011. Interaction between Shallow and Deep Groundwater Components at Fay Spring in the Northern Shenandoah Valley Karst. In: Kuniansky EL, 2011, U.S. Geological Survey Karst Interest Group Proceedings, Fayetteville, Arkansas, April 26-29, 2011, U.S. Geological Survey Scientific Investigations Report 2011-5031, pp. 25-34. https://pubs.er.usgs.gov/publication/sir20115031.

Johnson CD, Joesten PK, Mondazzi RA. 2005.

Borehole-Geophysical and Hydraulic Investigation of the Fractured-Rock Aquifer near the University of Connecticut Landfill, Storrs, Connecticut, 2000 to 2001. U.S. Geological Survey Water-Resources Investigations Report 2003-4125. 133 p. https:// pubs.er.usgs.gov/publication/wri034125.

Sheets R. Groundwater-Level Response to Virginia Earthquake, August 23, 2011 [Internet]. 2016 [Place of publication unknown]: U.S. Geological Survey; [updated 2016 December 29; cited 2017 September 25] Available from: https://water.usgs. gov/ogw/eq/VAquake2011.html.

Nelms DL, Moberg RM, Jr. 2010. Hydrogeology and groundwater availability in Clarke County, Virginia: U.S. Geological Survey Scientific Investigations Report 2010-5112, 119p. https:// pubs.er.usgs.gov/publication/sir20105112.

Taylor C, Alley W. 2001. Ground-water-level monitoring and the importance of long-term water-level data. US Geological Survey Circular; 1217, 68p. https://pubs.er.usgs.gov/publication/ cir1217.

Rader EK. 1967. Geology of the Staunton, Churchville, Greenville, and Stuarts Draft Quadrangles, Virginia. Virginia Division of Mineral Resources Report of Investigations; 12. 43p. https://www. dmme.virginia.gov/commerce/ProductDetails. aspx?productID=2392.

White W. 1988. Geomorphology and hydrology of karst terrains. New York, NY: Oxford University Press. 
